Helena Jazbec

Inštitut za slovenski jezik Frana Ramovša ZRC SAZU

\title{
Slovene štepselj and štofeljc
}

Tako sln. štépselj -na m 'majhen, debelušen človek' kot Sn štófeljc - $a$ m 1. 'zamašek' 2. ekspr. 'majhen človek' sta mladi nemški izposojenki, katerih predlogi sta etimološko povezani besedi z različnima sufiksoma: bav. n. Stepsl $-s \mathrm{~m} \mathrm{1}$. 'zamašek' 2. ekspr 'majhen, debelušen človek' in bav. n. Stoppel $-s$ m 'isto'. Spremljajo ju izposojeni glagoli, ki vplivajo na njune fonetične lastnosti. V nekaterih drugih slovanskih jezikih in $\mathrm{v}$ madžarščini poznajo podobne izposojenke. Vsi ti jeziki so tako kot slovenščina sosedi bavarsko-avstrijske nemščine, ki mora torej biti neposredni jezik dajalec.

Both Sn štépselj -na m 'a small, plump person' and Sn štófeljc - $a$ m 1. 'something (e.g., a bung or cork) used to plug an opening' 2. expr 'a small person' are recent German loanwords, based on two etymologically connected words with different suffixes: BA Stepsl $-s \mathrm{~m}$ 1. 'something (e.g., a bung or cork) used to plug an opening' 2. expr 'a small, plump person' and Bav Stoppel $-s$ m 'idem' respectively. They are accompanied by a group of loaned verbs, which influence their phonetic features. There are similar loans in some other Slavic languages and in Hungarian, like Slovene all neighbors of Bavarian Austrian, which proves to be their direct source.

1. The Sn word štépselj -na $\mathrm{m}(e ́)$ began to attract my attention when historian Branko Marušič inquired about its meaning. ${ }^{1,2}$ He came across this word in an article entitled $V$ Gorico!, written by a Slovene soldier in the first world war Metod Golmajer, published on the $25^{\text {th }}$ of October 1928 in Slovenec (No. 245): Spričo vsega tega smo se mi zadržali popolnoma mirno, mnogo je pa padlo pikrih na račun poljubljajočih se "štepselnov", katerih so bila samo kapa in ušesa... The word is not listed in the Slovar slovenskega knjižnega jezika (SSKJ), nor was I able to find it in the archives that served as the basis for this dictionary. Evidently it isn't a standard Slovene word. Considering the fact that Metod Golmajer lived in Ljubljana, I was not suprised to learn that the majority of my sources that are familiar with the word also comes from Ljubljana. Lučka Uršič, Alenka Porenta, Zvonka Praznik, Martin Ahlin and Andreja Hočevar, all from Ljubljana, use Sn štépselj -na m in the meaning 'a small, plump person' with a slightly pejorative or humorous connotation. I interviewed 18 other sources from other parts of Slovenia, but only Milka Špindlar from Maribor and Jan Vinkl from Mežica were familiar with this word in a slightly different meaning, expr 'a small person'. M. Špindlar uses the alternative genitive

\footnotetext{
${ }^{1}$ For help in acquiring the information on lexical material I would like to thank the members of the Fran Ramovš Institute of the Slovenian Language: Rožamarija Lučka Uršič, Alenka Porenta, Zvonka Praznik, Martin Ahlin, Jakob Müller, Aleksandra Bizjak, Andreja Žele; Branko Marušič (Milko Kos Institute of History); and all my other sources: Andreja Hočevar, Hannah Starman, Domen Smole, Tatjana Veljanovski, Tomaž Pavčnik, Tadeja Kern, Miroslav Bohinc, Jerneja Pevec, Nataša Breznik, Milka Špindlar, Vanja Peršič, Mojca Hrabar, Nataša Jazbec, Klemen Zakšek, Leja and Ivan Mauko, Petra Plavčak, Martina Maljevec, Igor Peternel and Jan Vinkl.

${ }^{2}$ The word material quoted is marked with signs for dynamic stress. The pitch-accent is marked in parenthesis.
} 
form štépslja, which is a usually the other option with German loanwords in Slovene, ending in -elj (compare kremplja : krempeljna in Bajec 1950: 35).

1.1 Sn štépselj 'a small, plump person' proves to be a loan from BA Stepsl $-s$ m 1. 'something (e.g., a bung or cork) used to plug an opening', 2. expr 'a small, plump person' (Wehle 1980: 266), which is a delabialized version of NHG Stöpsel $-s \mathrm{~m}$ 'idem', the latter being first attested in the $17^{\text {th }}$ century (Grimm 1999: XIX, 355-7; Küpper 1984: 2748). NHG Stöpsel is a derivation with the suffix -sel from the NLG/NMG verb stoppen 'to plug up'. Deverbal nouns like Anhängsel 'a pendant', Einschiebsel 'an insertion' or Rätsel 'a riddle, a mystery' that follow the same word-formation pattern as Stöpsel are of the neuter gender. The masculine gender of Stöpsel is therefore supposed to be the result of the association with the following synonymous nouns: Stopfen $-s \mathrm{~m}$ 'something (e.g., a bung or cork) used to plug an opening', Korken -s m 'idem', Pfropfen $-s$ m 'idem' (Pfeifer 2000: 1369-70).

2. Besides NHG Stöpsel, BA Stepsl there are some other synonymous deverbal nouns that comprise a word family in German and yield additional loans in Slovene. First let us examine these NHG nouns: originally Low German, today mainly Bavarian Stoppel $-s \mathrm{~m}$ 1. 'something (e.g., a bung or cork) used to plug an opening', 2. expr 'a small person' (Grimm 1999: XIX, 343; Küpper 1984: 2747; Duden 2001: 1525; Schierer-Zauner 2002: 78) and NHG Stöpfel $-s$ m 1. 'something (e.g., a bung or cork) used to plug an opening', 2. expr 'a small, plump person' (Grimm 1999: XIX, 308; Hügel 1873: 158). NHG Stoppel is a derivation with the suffix -el from the NLG/NMG verb stoppen 'to plug up', while NHG Stöpfel follows the same derivation pattern, yet using the NHG version of the verb: stopfen 'idem' that shows the reflex of the second (or the OHG) consonant change $-p p$ - $>-p f$ - (in OHG texts written also as -ph-): OHG stophon (first attested in the $9^{\text {th }}$ century), MHG stopfen, NHG stopfen 'to plug up'. OHG stophōn originally meant 'to sting, to pierce', influenced by the ML stuppare 'to plug up with spinning material' OHG stophon acquired the meaning 'to plug up'. There is also an OHG derivation with a prefix, first attested in the $11^{\text {th }}$ century firstophōn 'to make or become tight, impermeable', MHG and NHG verstopfen 'idem'. These verbs are connected with IE *(s)teup-, *(s)teub $(h)$ - 'to push' (Pfeifer 2000: 1369-70). We shall see that they left echoes in Slovene too.

3.1 In the archives that served as the basis for SSKJ I found the word Sn štófeljc - $a$ m expr 'a small person': - Da bi vsaj nosila hlače, reče. - Figo boš dobila, reče. Si preveč štofeljc (Šeligo 1975: 13). In Slovar poljanskega narečja the word has a different meaning štóflc 'something (e.g., a bung or cork) used to plug an opening' (Škrlep 1999: 60). Most of my sources confirmed the second meaning, only some of them also the first one. In contrast with the predominately in Ljubljana used word štépselj the word štófeljc is used almost all over Slovenia. Miroslav Bohinc and Domen Smole also use it to refer to 'a traffic jam'. J. Vinkl reports a variation without the suffix -c: štófelj -na m (ô) 'something (e.g., a bung or cork) used to plug an opening'. In addition to štófeljc four of the people I interviewed also use Sn štópeljc - $a \mathrm{~m}$ synonymously. Finally, there is also the version with - $p$ and without the suffix $-c$ : Sn štópelj -na m, known to M. Špindlar both in the material and in the metaphorical meaning and to Lea Mauko only as 'something (e.g., a bung or cork) used to plug an opening'. Those familiar with štópelj(c) come from various parts of Slovenia. 
3.1.1 Sn štópelj(c) 1. 'something (e.g., a bung or cork) used to plug an opening', 2. expr 'a small person' is a loan from NHG Stoppel 'idem'. The suffix $-c$ is of Slovenian origin and carries the grammatical meaning of nomen instrumenti, thus being a morphemic substitution for the German -el, a suffix for nomina instrumenti in German. In other words, since the suffix $-e l$ loses its grammatical function after the importation of the word into the Slovene language system, the system offers a Slovene suffix to substitute the loss.

3.1.2 Sn štófelj(c) 1. 'something (e.g., a bung or cork) used to plug an opening', 2. expr 'a small person' requires a NHG *Stopfel 'idem' as the basis for the loaning, for Sn $f$ has been the regular substitution for the NHG/MHG $p f$ since the 12-th century as in: Bav Pfeife 'a pipe' $\rightarrow$ Sn fâjfa 'idem', Bav kupfer 'copper' $\rightarrow$ Sn kúfer 'idem' (Striedter-Temps 1963: 31). However I could't find *Stopfel in German dictionaries. It is only the version with an umlaut Stöpfel 1. 'something (e.g., a bung or cork) used to plug an opening', 2. expr 'a small person' that is attested, but this word as a loan would yield an -e- in Slovene, since the Bav $\ddot{o}$ was delabialized to $e$ in the $13^{\text {th }}$ century (compare NHG Knödel 'a dumpling' > Bav knedl $\rightarrow$ Sn knédelj 'idem' in Striedter-Temps 1963: 8). There are two solutions to this problem:

a) The development Sn štópeljc > štófeljc is the result of the association with the verb Sn zaštófati (se) -am (se) pf 'to plug up; to become blocked', semantically and etymologically related to the noun. Namely $88 \%$ of my sources familiar with the version zaštófati (and not Sn zaštópati (se) -am se pf 'idem') also use štófeljc and not štópeljc.

b) A Bav *Stopfel could exist, for there are many cases in Bav, where there are both the version with and the one without an umlaut like for example: Bav

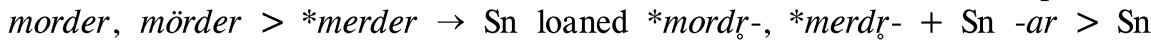
mordrar, merdrar 'idem' (Striedter-Temps 1963: 181). However, since Bav *Stopfel is not attested and it also does not belong to any of the groups of words with specific suffixes or specific consonants following the vowel that regularly remained without an umlaut, the solution in a) is more likely.

3.1.2.1 The metaphorical meaning of Sn štófeljc 'a traffic jam' has developed in Slovene, yet probably under the influence of the verb NHG stopfen 'to cause a traffic jam': Die Strassen waren sämmtlich mit fussgängern und nur langsam vorwärts rückenden wagen gestopft (Grimm 1999: XIX, 312).

3.2 Since the loaned nouns described are semantically interwoven with some loaned verbs, let us devote some attention to the later as well. Most of the sources use either Sn zaštófati (se) -am (se) pf 'to plug up; to get blocked' or Sn zaštópati (se) -am (se) pf 'idem'. The words are spoken all over Slovenia. Sn zaštófati also appears in the archives for SSKJ. The Slovar beltinskega prekmurskega govora has zaštòpati -an pf 'to plug up, to sew a hole in textile', the shortness of the vowel being a dialectal feature (Novak 1985: 131). Lea and Ivan Mauko from Radenci, Igor Peternel from Maribor and a small dictionary of the Maribor speech (Zorko 2002: 144) familiarized me with an interesting version of this verb, i.e., Sn zaštópfati se -am se pf 'to become blocked'. The consonant sequence $p+f$ in Slovene is loaned from German without any phonetical adjustment to the Slovene phonological system. The only adaptation to the Slovene system is the fact that Slovene $p f$ is a sequence of 
two phonemes, while in German $p f$ is one phoneme (affricate). We can refer to this as a trans-phonemization (Filipović 1971: 119).

3.2.1 L. Uršič, Nataša Jazbec and M. Bohinc, each from different parts of Slovenia, use Sn štópati nogavice -am impf 'to sew a hole in socks or stockings by making a net with the thread', while J. Vinkl from Mežica uses the version with an $f$ štófati -am impf $(\hat{o})$ in a broader meaning 'to sew'.

3.2.2 German verbs that served as the basis for loaning into Slovene existed already in OHG. However in my opinion the loaning process took place in the time of NHG, as it is also the case with the loaned nouns. There are two reasons to believe this:

a) Sn zaštófati (se), zaštópati (se), zaštópfati se, štópati nogavice and štófati do not preserve the OHG meaning 'to push, strike'.

b) The German meaning 'to sew a hole in textile by making a net with the thread', also found in Sn štópati nogavice, is attested in NHG only in the $18^{\text {th }}$ century and no earlier (Pfeifer 2000: 1369-70).

3.3 The loaning formulas for the $\mathrm{Sn}$ verbs are as follows:

a) NHG (sich) verstopfen ${ }^{3}$ 'to plug up; to become blocked' $\rightarrow$ Sn loaned -štóf+ Sn $z a-+$ Sn -a-ti se 'idem', where $z a$ - is a Sn prefix calqued on NHG ver-, $\mathrm{Sn} s e$ is a reflexive free verbal morpheme calqued on NHG sich, and -a-ti are an originally Slovene verb suffix and an infinitive ending.

b) BA (sich) verstoppen ${ }^{4}$ 'to plug up; to become blocked' $\rightarrow$ Sn loaned -štóp- + Sn $z a-+$ Sn -a-ti se 'idem', where $z a$ - is a Sn prefix calqued on NHG ver-, Sn $s e$ is a reflexive free verbal morpheme calqued on NHG sich, and $-a-t i$ are an originally Slovene verb suffix and an infinitive ending.

3.3.1 The Sn morphemic-semantic substitution $z a$ - for the NHG prefix ver- is not unusual in Slovene loaned verbs: NHG ver-spielen 'to lose in gambling (eg. money, other property etc.)' $\rightarrow$ Sn loaned $-\check{s} p i ́ l-+$ Sn $z a-+$ Sn $-a-t i>$ Sn Pan $z a-$ šilati -an pf 'idem' (Novak 1985: 176) or Sn Car zašpílat pf 'idem' (Karničar 1990: 33). NHG spielen 'to play', etc., cannot be the basis for loaning, for this verb does not have the meaning 'to lose in gambling' (Grimm 1999: XVI, 2325-88). Therefore the Sn prefix $z a$ - in zašpilati can only be calqued on the German prefix ver- and not a Slovene addition to the Sn loaned špilati -am impf 'to play' $\leftarrow$ NHG spielen 'idem'.

c) Originally Low German, today also BA stoppen ${ }^{5}$ 'to plug up; (sich s.) to become blocked; to sew a hole in textile by making a net with the thread' etc. $\rightarrow$ Sn štópati nogavice 'to sew a hole in socks, stockings by making a net with the thread'.

d) NHG stopfen $^{6}$ 'to plug up; (sich s.) to become blocked; to sew a hole in textile by making a net with the thread' $\rightarrow \mathrm{Sn}$ loaned štóf $-+\mathrm{Sn}-a-t i>\mathrm{Sn}$

${ }^{3}$ Grimm 1999: XXV, 1765-71.

${ }^{4}$ Grimm 1999: XXV, 1765-71.

${ }^{5}$ Striedter-Temps 1958: 210; Grimm 1999: XIX, 308-326.

${ }^{6}$ Grimm 1999: XIX, 308-326. 
štófati 'to sew', known only to J. Vinkl, as mentioned above. J. Vinkl also reports zaštófati -am pf 'to sew a hole in textile', which has been built by adding the Sn prefix $z a$ - to Sn štófati 'to sew', for NHG verstopfen does not have the meaning 'to sew a hole in textile' and thus cannot be the loan basis in this case (Grimm XXV, 1765-71).

3.4 The meaning of Sn štófati 'to sew' is broader than the meaning of the NHG stopfen 'to sew a hole in textile', which is rare, but not unknown, in the process of loaning. Filipović gives an example of widening the meaning of the loanword in relation to the foreign basis: $\mathrm{Cr}$ najlon 1. 'artificial fibers used for weaving textiles' 2. 'plastics' $\leftarrow$ ENG nylon 'artificial fibers used for weaving textiles' (Filipović 1971: 140). The second meaning in $\mathrm{Cr}$ is from the synchronic point of view the result of decreasing the number of semantic elements (sems): plastics (sem 1) + for $($ sem 2 (instrumental)) + weaving (sem 3$)+$ textiles (sem 4$) \rightarrow$ only sem 1 . Similarly there is a reduction in sems in our case: Sn štófati: sew (sem 1) + holes (sem 2) + in (sem 3 (local)) + textiles (sem 4$) \rightarrow$ only sem 1 .

4. Finally, I would like to mention some similar German loanwords in other Slavic languages and in Hungarian. Many of them are nouns meaning 'something (e.g., a bung or cork) used to plug an opening': - Sk dial štopel -pla $\mathrm{m} \leftarrow$ Bav Stoppel 'idem' (Stanislav 1932: 138; Orlovský 1982: 340); - Cz dial štepsl -u m 'idem' $\leftarrow$ BA Stepsl 'idem' (Havránek 1989: VI, 76); - Hu stopli 'idem' $\leftarrow$ Bav Stoppel 'idem' $(E W U 1360)^{7}$; - Cr štòplciger $\mathrm{m}$ 'an opener for bottles with a cork' $\leftarrow$ BA Stoppelzieher -s m 'idem' (Anić 1994: 1042; Grimm 1999: XIX, 352). The other group of loanwords are verbs: - Cr reg zàštopati (se) pf 'to plug up; to become blocked' $\leftarrow$ BA verstoppen 'idem' (Anić 1994: 1219) and $\mathrm{Cr}$ dial štòpati -am impf 'to sew up holes in textile' $\leftarrow$ BA stoppen 'to sew a hole in textile by making a net' (Tornow 1989: 338); - Sk dial štopkat -ám 'to sew up a hole in textile by making a net' (Orlovský 1982: $340) \leftarrow$ BA stoppen 'idem'; - Hu stoppol 'to sew up holes in clothes' $\leftarrow$ BA stoppen 'to sew up a hole in textile by making a net' (EWU 1361), -ol being a $\mathrm{Hu}$ deverbative suffix, also known in other loaned verbs: Hu kóstol 'to taste' $\leftarrow$ NHG kosten 'idem', Hu pucol 'to clean' $\leftarrow$ NHG putzen 'idem' (Benkô - Imre 1972: 152-3). The present loanwords in Slovene, Croatian, Hungarian, Slovak and Czech form almost a perfect circle around the Bavarian Austrian territory and prove this dialect of German to be their direct source.

\section{Abbreviations}

$\mathrm{BA}=$ Bavarian Austrian, Bav $=$ Bavarian German, Car $=$ Carinthian dialect, $\mathrm{Cr}=$ Croatian, $\mathrm{Cz}=$ Czech, dial $=\operatorname{dialect}(\mathrm{al}), \mathrm{ENG}=$ English, expr $=$ expressive, $\mathrm{Hu}=$ Hungarian, $\mathrm{IE}=$ Indo-European, $\mathrm{impf}=$ imperfective, $\mathrm{m}=$ masculine, $\mathrm{ML}=$ Medieval Latin, MHG = Middle High German, NHG = New High German, NLG $=$ New Low German, NMG = New Middle German, OHG = Old High German, Pan = Pannonian dialect, $\mathrm{pf}=$ perfective, $\mathrm{reg}=$ regional, $\mathrm{Sk}=$ Slovak, $\mathrm{Sn}=$ Slovene

\footnotetext{
${ }^{7}$ The substitution of the German suffix $-e l$ with the Hungarian suffix -li is typical for German loanwords in Hungarian: Hu bicikli 'bicycle' $\leftarrow$ NHG Bizykel 'idem' (EWU 104), Hu cetli 'a small piece of paper' $\leftarrow$ NHG Zettel 'idem' (EWU 164).
} 


\section{References}

Anić, V. 1994. Rječnik hrvatskoga jezika. Drugo, dopunjeno izdanje. Zagreb: Novi Liber.

$E W U=$ Benkő, L. (Hrsg.), K. Gerstner, A. S. Hámori, G. Zaicz, B. Büky, E. Hexendorf and L. Horváth. 1993-. Etymologisches Wörterbuch des Ungarischen. Budimpešta: Akadémiai kiadó.

Benkô, L., and S. Imre. 1972. The Hungarian Language. Budapest: Akadémiai kiadó.

Duden = Klosa, A., K. Kunkel-Razum, W. Scholze-Stubenrecht and M. Wermke, (alle Hrsg.). 2001. Duden. Deutsches Universalwörterbuch. 4., neu bearbeitete und erweiterte Auflage. Mannheim - Leipzig - Wien - Zürich: Dudenverlag.

Filipović, R. 1971. Kontakti jezika u teoriji i praksi. Zagreb: Školska knjiga.

Grimm, J. and W. 1999. Deutsches Wörterbuch I-XXXIII. Nachdruck der Erstausgabe 1854-1984. München: Deutscher Taschenbuch Verlag.

Havránek, B. (ed.). 1989. Slovník spisovného jazyka českého I-VIII. Praha: Academia.

Hügel, F. S. 1873. Der Wiener Dialekt. Lexikon der Wiener Volkssprache. Wien - Pest - Leipzig: A. Hartlebens' Verlag.

Karničar, L. 1990. Der Obir-Dialekt in Kärnten. Wien: Verlag der Österreichischen Akademie der Wissenschaften.

Küpper, H. 1984. Illustriertes Lexikon der deutschen Umgangssprache in 8 Bänden. Stuttgart: E. Klett Verlage.

Novak, F. 1985. Slovar beltinskega prekmurskega govora. Dopolnil in uredil Vilko Novak. Murska Sobota: Pomurska založba.

Orlovský, J. 1982. Gemerský nárečový slovník. Rimavská Sobota: Vydavatel'stvo Osveta.

Pfeifer, W. 2000. Etymologisches Wörterbuch des Deutschen. 5. Auflage. München: Deutscher Taschenbuch Verlag.

Ramovš, F. 1924. Historična gramatika slovenskega jezika II. Konsonantizem. Ljubljana: Učiteljska tiskarna.

Schierer, A., and T. Zauner. 2002. Sprechen Sie Österreichisch? Ein Sprachführer für Einheimische und Zugereiste. Wien: Carl Ueberreuter.

Slovenec. Političen list za slovenski narod. 1873-1945. Ljubljana: Ljudska tiskarna.

SSKJ = Slovar slovenskega knjižnega jezika I-V. 1970-1991. Ljubljana: DZS.

Stanislav, J. 1932. Liptovské nárečia. 15 obrazov a 12 máp. Turčiansky Sv. Martin: Matica Slovenska.

Striedter-Temps, H. 1958. Deutsche Lehnwörter im Serbokroatischen. Berlin: Osteuropa-Institut.

Striedter-Temps, H. 1963. Deutsche Lehnwörter im Slovenischen. Berlin: Osteuropa-Institut.

Šeligo, R. 1975. Rahel stik. Ljubljana: Mladinska knjiga.

Škrlep, D. 1999. Slovar poljanskega narečja. Gorenja vas: Gostilna Poni. 
Tornow, S. 1989. Burgenlandkroatisches Dialektwörterbuch. Die vlahischen Ortschaften. Berlin: Otto Harrassowitz.

Wehle, P. 1980. Sprechen Sie Wienerisch? Wien - Heidelberg: Verlag Carl Ueberreuter.

Zorko, Z. 2002. Mariborski pogovorni jezik. Studia Historica Slovenica. Časopis za humanistične in družboslovne študije 2/1: 127-50.

Prispelo oktobra 2003, sprejeto decembra 2003

Received October 2003, accepted December 2003

\section{Slovensko štepselj in štofeljc}

Sln. štépselj -na m 'majhen, debelušen človek' $\mathrm{z}$ rahlo zaničevalnim ali hudomušnim prizvokom poznajo predvsem Ljubljančani. Izposojeno je iz bav. n. Stepsl $-s$ m 1. 'zamašek', 2. ekspr. 'majhen, debelušen človek', kar je delabializirana varianta iz nvn. Stöpsel $-s$ m 'isto', ki je bilo prvič izpričano v 17. stoletju. Nvn. Stöpsel je izpeljanka s sufiksom -sel iz nspn./srspn. glagola stoppen 'zamašiti'. Poleg bav. n. Stepsl sta bila iz nemščine $\mathrm{v}$ slovenščino izposojena še naslednja sinonimna izglagolska samostalnika: izvorno nizkonemško, danes pretežno bavarsko Stoppel $-s$ m 1. 'zamašek', 2. ekspr. 'majhen človek' in mogoče tudi nvn. Stöpfel $-s$ m 1. 'zamašek', 2. ekspr. 'majhen, debelušen človek'. Nvn. Stoppel je izpeljanka s sufiksom -el iz nspn./srspn. glagola stoppen 'zamašiti', medtem ko je nvn. Stöpfel izpeljano po istem besedotvornem vzorcu, le da iz nvn. različice glagola: stopfen 'isto', ki kaže refleks drugega (ali stvn.) soglasniškega premika: $-p p->-p f-$.

V nasprotju s sln. štépselj, ki se govori pretežno v Ljubljani, je sln. štófeljc -a m 1. 'zamašek', 2. ekspr. 'majhen človek' znan skoraj po vsej Sloveniji. Ima več različic: štófelj -na m, štópeljc - $a \mathrm{~m}$, štópelj -na m. Sln. štópelj(c) 1. 'zamašek', 2. ekspr. 'majhen človek' je izposojeno iz nvn. Stoppel 'isto'. Sufiks $-c$ je slovenski in ima slovnični pomen nomena instrumenti, tako da predstavlja morfemsko substitucijo za nemški -el, kar je sufiks za nomina instrumenti v nemščini. Razvoj sln. štópeljc > štófeljc je posledica vpliva izposojenega glagola sln. zaštófati (se) -am se pf. 'zamašiti (se)', ki je temu samostalniku pomensko in etimološko soroden. Kar 88 odstotkov anketiranih, ki poznajo glagolsko različico zaštófati (in ne sln. zaštópati (se) -am se pf. 'isto'), uporablja tudi štófeljc in ne štópeljc. Manj verjetno pa je, da je sln. štófeljc izposojeno iz bav. n. nepreglašene različice *Stopfel 1. 'zamašek', 2. ekspr. 'majhen, debelušen človek’ k sicer izpričanemu nvn. Stöpfel.

Sn zaštófati (se) -am (se) dov. 'zamašiti (se)' ali sln. zaštópati (se) -am (se) dov. 'isto’ se govorita po vsej Sloveniji. V različnih krajih po Sloveniji je znano tudi sln. štópati nogavice -am nedov. 'krpati luknje $\mathrm{v}$ nogavicah, tako da iz niti nastane mreža'. J. Vinkl iz Mežice uporablja različico štófati -am nedov. s širšim pomenom ‘šivati'. Formulo izposoje pri sln. predponskih glagolih lahko zapišemo takole: nvn. (sich) verstopfen 'zamašiti (se)' $\rightarrow$ sln. izposojeno -štóf $-+\operatorname{sln} . z a-+\operatorname{sln} .-a-t i$ se 'isto', pri čemer je $z a$ - sln. predpona, kalkirana po nvn. ver-, sln. se je povratnoosebni prosti glagolski morfem, kalkiran po nemškem sich, - $a$ - in - $t i$ pa sta slovenska glagolska pripona in nedoločniška končnica. Podobno velja za različico glagola s - $p$-jem: bav. $\mathrm{n}$. (sich) verstoppen 'zamašiti (se)' $\rightarrow \operatorname{sln}$. izposojeno -štóp- $+\operatorname{sln} . z a-+\operatorname{sln} .-a-t i$ se 'isto'. In še predloge za sln. glagole brez predpon: bav. n. stoppen 'zamašiti; (sich s.) 
zamašiti se; zašiti luknjo v tkanini, tako da iz niti nastane mreža' itd. $\rightarrow$ Sn štópati nogavice 'krpati luknje $\mathrm{v}$ nogavicah, tako da iz niti nastane mreža'; nvn. stopfen 'zamašiti; (sich s.) zamašiti se; zašiti luknjo v tkanini, tako da iz niti nastane mreža' itd. $\rightarrow$ sln. štófati ‘šivati’.

Podobne izposojenke najdemo tudi $\mathrm{v}$ nekaterih drugih slovanskih jezikih in $\mathrm{v}$ madžarščini. Nekatere so samostalniki s pomenom 'zamašek': slš. dial štopel -pla m, č. dial. štepsl $-u$ m in madž. stopli, druge pa so glagoli: hrv. pokr. zàštopati (se) dov. 'zamašiti (se)', hrv. dial. štòpati -am nedov. 'zašiti luknje v tkanini', slš. dial. štopkat -ám 'krpati luknje $\mathrm{v}$ tkanini, tako da iz niti nastane mreža' in madž. stoppol 'zašiti luknje v oblačilih'.

\section{Slovene štepselj and štofeljc}

Sn štépselj -na m 'a small, plump person' with a slightly pejorative or humorous connotation is known primarily to inhabitants of Ljubljana. It proves to be a loan from BA Stepsl $-s \mathrm{~m}$ 1. 'something (e.g., a bung or cork) used to plug an opening', 2. expr 'a small, plump person', which is a delabialized version of NHG Stöpsel $-s$ m 'idem', the latter being first attested in the 17-th century. NHG Stöpsel is a derivation with the suffix -sel from the NLG/NMG verb stoppen 'to plug up'. Next to BA Stepsl there are some other synonymous deverbal nouns in German that have been loaned into Slovene: originally Low German, today mainly Bavarian Stoppel $-s \mathrm{~m} 1$. 'something (e.g., a bung or cork) used to plug an opening', 2. expr 'a small person' and maybe also NHG Stöpfel $-s \mathrm{~m} \mathrm{1}$. 'something (e.g., a bung or cork) used to plug an opening', 2. expr 'a small, plump person'. NHG Stoppel is a derivation with the suffix -el from the NLG/NMG verb stoppen 'to plug up', while NHG Stöpfel follows the same derivation pattern, yet using the NHG version of the verb: stopfen 'idem' that shows the reflex of the second (or the OHG) consonant change $-p p->-p f-$.

In contrast with the word spoken predominately in Ljubljana, štépselj, the Sn word štófeljc - $a \mathrm{~m} \mathrm{1}$. 'something (e.g., a bung or cork) used to plug an opening' 2. expr 'a small person' is used almost all over Slovenia. It has some variants: štófelj -na $\mathrm{m}$, štópeljc - $a \mathrm{~m}$, štópelj -na m. Sn štópelj(c) 1. 'something (e.g., a bung or cork) used to plug an opening', 2. expr 'a small person' is a loan from NHG Stoppel 'idem'. The suffix $-c$ is of Slovenian origin and carries the grammatical meaning of nomen instrumenti, thus being a morphemic substitution for the German -el, a suffix for nomina instrumenti in German. The development $\mathrm{Sn}$ štópeljc > štófeljc is the result of the association with the verb Sn zaštófati (se) -am se pf 'to plug up; to become blocked', semantically and etymologically related to the noun. To wit, $88 \%$ of my sources familiar with the version zaštófati (and not $\mathrm{Sn}$ zaštópati (se) -am se pf 'idem') also use štófeljc and not štópeljc. It is less likely that Sn štófeljc is loaned from an unattested BA variant without umlaut *Stopfel 1. 'stopper', 2. expr 'small, plump person', that could have existed alongside the attested before the previously mentioned NHG term Stöpfel.

Sn zaštófati (se) -am (se) pf 'to plug up; to become blocked' or Sn zaštópati (se) -am (se) pf 'idem' are used all over Slovenia. There is also Sn štópati nogavice -am impf 'to sew a hole in socks, stockings by making a net with thread' used in different parts of Slovenia, while J. Vinkl from Mežica uses the version with an $f$ štófati 
- am impf in the broader meaning 'to sew'. The loaning formula for the Sn verbs with prefixes appears to be: NHG (sich) verstopfen 'to plug up; to become blocked' $\rightarrow \mathrm{Sn}$ loaned -štóf- $+\mathrm{Sn} z a-+\mathrm{Sn}-a-t i$ se 'idem, where $z a$ - is a Sn prefix calqued on NHG ver-, Sn se is a reflexive free verbal morpheme calqued on NHG sich, and $-a-t i$ are an originally Slovene verb suffix and an infinitive ending. Similarly for BA (sich) verstoppen 'to plug up; to become blocked' $\rightarrow \mathrm{Sn}$ loaned -štóp- $+\mathrm{Sn} z a-+\mathrm{Sn}$ $-a$ - $t$ i se 'idem'. And the loan bases for the $\mathrm{Sn}$ verbs without prefixes: BA stoppen 'to plug up; (sich s.) to become blocked; to sew a hole in textile by making a net with the thread' etc. $\rightarrow$ Sn štópati nogavice 'to sew a hole in socks, stockings by making a net with the thread'; NHG stopfen 'to plug up; (sich s.) to become blocked; to sew a hole in textile by making a net with the thread' $\rightarrow$ Sn štófati 'to sew'.

There are some similar German loanwords in some other Slavic languages and in Hungarian. Some of them are nouns meaning 'something (e.g., a bung or cork) used to plug an opening': Sk dial štopel -pla m, Cz dial štepsl $-u \mathrm{~m}$ and $\mathrm{Hu}$ stopli and some are verbs: $\mathrm{Cr}$ reg zàštopati (se) pf 'to plug up; to become blocked', Cr dial štòpati -am impf 'to sew holes in textile', Sk dial štopkat -ám 'to sew a hole in textile by making a net' and Hu stoppol 'to sew holes in clothes'. 